\title{
Challenges and their overcoming when implementing the restructuring of children's care homes in Lithuania
}

\author{
Vida Gudzinskiene and Rita Raudeliunaite \\ Mykolas Romeris University, Vilnius, Lithuania
}

\begin{abstract}
The aim of the study is to reveal challenges and the ways to overcome them in the context of the restructuring of childcare, based on the experience of social workers who work in children's care homes, which participate in the restructuring. Qualitative research type was chosen for the study. The method of a semi-structured interview with social workers who work in care institutions, that take part in the deinstitutionalisation process. The challenges arising to social workers in the context of the restructuring, which came to light during the study, are related to the resistance and anxiety of social workers regarding their future, the lack of information on the restructuring, the lack of engagement of social workers in the restructuring processes, the lack of the dissemination of good practices, the need to improve professional qualifications and the possibility to choose training courses of qualification improvement which correspond to their needs. The unpreparedness of the community for the restructuring, as well as the finding of foster parents and adoptive parents for children or the reunification with their family and the anxiety of the children about their future were also identified. In order to overcome the challenges arising during the restructuring it is necessary: to have a restructuring plan which is clear and understandable to all, the preparation of the employees for changes, the increase of dissemination of information in the communityand society, the rallying of the community, inter-institutional cooperation and the preparation of parents/ adoptive parents/foster parents.
\end{abstract}

Key words: deinstitutionalisation, care homes, family and communitybased care, children, parents, adoptive parents, foster parents, social worker.

\section{Introduction}

In 2016, according to the data of State Child Rights Protection and Adoption Service [1], 518 201 children under 18 years of age were living in Lithuania. Out of them, 9106 children were in care: $65 \%$ of all the children in care were growing in the families of their foster parents and $35 \%$ were growing in care homes. Although the number of the children in care homes is decreasing, a significant proportion of children, who were placed in care, are growing in care homes.

The studies conducted in Lithuania and Europe demonstrated that institutional care always result lower quality of life than quality services provided in the community and often result lifelong social exclusion [2-7]. The scientific studies on early child development required by the World Health Organisation and the United Nations demonstrate that, in the case of very little children, even relatively brief period of a stay in the institution might adversely affect the child's development and result in lifelong negative consequences for emotional well-being and behaviour ofchildren [8]. The studies demonstrate that mental 
development of children, who live in care homes, slows down due to the lack of quality relationships and meaningful communication with the adults [9]. The scientists also draw attention to the fact that living conditions in care homes can cause different problems in children within a field of their health, cognition, emotions and morality [10-12]. Care homes are not designed for a child's positive socialisation, because these institutions, although they have sufficiently good financial resources, are not comparable with family environment, it is impossible to safeguard child's individual needs, and in particular quality relationships with the adults. C.M. Connell, R.J. Prinz [13] claim that the child, who has close relationships with parents, has well developed social skills, whereas the child, who has not had any such relationships in the family, is characterised as lacking social skills, avoiding people, being aggressive and not able to control himself. Institutionalisation is increasingly recognised as a vicious policy and a violation of human rights.

The deinstitutionalisation of child care system has recently been one of the priority areas in Lithuanian social policy. The beginnings of the deinstitutionalisation of child care in Lithuanian social policy can be noticed in the Measures for Implementation of the Programme of the Government for 2001-2004 when it was foreseen to bring about the reform of child care system, giving priority to child care in the family and improving a support system for orphans and children deprived of parental care. The aspiration to reform childcare system was established in the Concept of Child Welfare [14], the Regulations on the organisation of child care [15] and in the Reorganisation strategy of Child Care Systemand the Plan for Its Implementation for 2007-2012 [16]. The most recent documents, which examine the issues of the deinstitutionalisation of child care system [17, 18], further emphasise the necessity for the transition from institutional to community-based social services, in order to safeguard harmonious environment and conditions for children deprived of parental care to grow with foster parents or adoptive parents and receive assistance in the community. Since 2008 Lithuania has started to implement foster parent preparation programme PRIDE (Parent Resources for Information, Development, and Education), which is carried out by certified social workers. The aspirations for the restructuring set out in the documents and proposals are rational and profound, however, as practice has shown, they are difficult to implement: there is still the lack of social services for families, the forms of alternative care, the legal regulation of child care forms has shortcomings, care forms being in force, are too strictly defined, temporary care is not flexible enough, legal framework, which would regulate emergency aid to the family having a crisis situation, has not been established yet [19].

The transition from institutional to family and community-based care is gradual. Political basis for that is important, however, not only authorities, but also care institutions themselves have to be involved in that. Therefore, while the restructuring is underway it is relevant to investigate what challenges social workers working in children's care homes, which participate in the restructuring, encounter, and while analysing the findings of the studies, to model strategies for overcoming arising problems, in order that the objectives set out in the restructuring would be achieved.

The aim of the study is to reveal challenges and the ways to overcome them in the context of the restructuring of childcare, based on the experience of social workers who work in children's care homes, which participate in the restructuring.

Problematic questions of the study: 1) what challenges arise during the restructuring of children's care homes; 2 ) how is it possible to overcome challenges related to the restructuring of care homes?

\section{Research methodology}

Qualitative research type was chosen for the study. The method of a semi-structured interview with social workers who work in care institutions that take part in the deinstitutionalisation 
process was used. The presented article overviews two problematic questions of the study: 1) what challenges arise during the restructuring of children's care homes; 2) how is it possible to overcome challenges related to the restructuring of care homes?

The obtained data were analysed using the content analysis method. Qualitative content analysis was carried out in accordance with the inductive, study data based and categories composed logic. Content analysis is a technique which, having examined the specificities of the text, allows, objectively and systematically, draw reliable conclusions [20]. The qualitative content analysis was made regarding the following sequence [20]: repeated reading of the content of transcript interview texts, distinction of meaning elements in the text analysed, the grouping of the distinguished meaning elements into categories and subcategories, the integration of the categories/sub-categories into the context of the phenomenon analysed and the description of their analysis.

Criteria-based sample was used in the study. The informants were chosen according to three criteria: 1) social workers who have a degree in social work, 2) social workers who work in care institutions that take part in restructuring, which consists of the transition from institutional care to services, which are provided to children, who have lost parental care, in a family and community; 3) social workers whose length of their working time in children's care homes is at least 5 years.

The study was conducted in the September-October of 2015 in 10 children's care homes chosen for the restructuring. 14 social workers (all female) participated in the study.

The permission of the heads of children's care homes to conduct the research in their organisation has been obtained. Personal permission of the informants to take part in the research was sought. The researchers obliged themselves to the research participants not to divulge the information related to the organisation and the informant. The principles of anonymity, volunteerism and benevolence were followed. The social workers were acquainted with the goal of the research, the interview questions, and the importance of justified reflection on their experience.

\section{Analysis of research results}

\subsection{Challenges arising during the deinstitutionalisation of children's care homes}

During the study social workers, who work in children's care homes, which participate in the restructuring, were asked to express their opinion on challenges arising during the restructuring of children's care homes. While analysing the answers obtained from the informants, three categories were distinguished: challenges arising to social workers, challenges which are related to society and community and challenges which are related to children (Table 1).

The success of the restructuring of institutional care depends on the appropriate preparation of social workers for the restructuring. Based on the opinion of the informants, not all of the employees of care are positively disposed to the restructuring: a portion of employees feel anxiety about their future, they are afraid to lose their job and social guarantees. According to the informants, the anxiety of social workers about the restructuring and resistance to it arises due to the lack of information on restructuring. The informants underlined that the originators and the implementers of the reforms "do not consult with social workers who work in care homes". Social workers resist and are anxious about the effectiveness of the reform, whether transition from institutional care to family and community-based services will be really implemented properly. They doubt as regards the declared changes due to different reasons: the projects which failed earlier, the lack of 
Table 1. Challenges in the context of the restructuring children's care homes.

\begin{tabular}{|c|c|}
\hline Category & Subcategory \\
\hline \multirow[t]{6}{*}{$\begin{array}{l}\text { Challenges } \\
\text { arising to social workers }\end{array}$} & $\begin{array}{l}\text { The resistance of social workers and their anxiety about the } \\
\text { future }\end{array}$ \\
\hline & The lack of information on restructuring \\
\hline & $\begin{array}{l}\text { Insufficient involvement of social workers in the restructuring } \\
\text { processes }\end{array}$ \\
\hline & The lack of the dissemination of good practices \\
\hline & Necessity to improve professional qualifications \\
\hline & $\begin{array}{l}\text { Challenges related to the supply and demand of the themes and } \\
\text { trainings of qualification improvement }\end{array}$ \\
\hline \multirow[t]{2}{*}{$\begin{array}{l}\text { Challenges related to } \\
\text { society and community }\end{array}$} & $\begin{array}{l}\text { Negative approach of the community towards the educatees of } \\
\text { children's care homes and resistance to the restructuring }\end{array}$ \\
\hline & The unpreparedness of the community for the restructuring \\
\hline \multirow[t]{2}{*}{$\begin{array}{l}\text { Challenges related to } \\
\text { children }\end{array}$} & $\begin{array}{l}\text { The finding of foster parents, adoptive parents for children or } \\
\text { the reunification with their family }\end{array}$ \\
\hline & The anxiety of children about their future \\
\hline
\end{tabular}

information and negative personal experiences. The distrust of employees is basically related to systemic problems. Similar tendencies were also revealed by the studies of other countries, in which the deinstitucionalization of care homes is carried out [21-24], showing the fears of employees to lose their jobs, limited sustainability of the deinstitutionalization projects, because some projects, which were carried out and are being carried out, are based on abstract ideas, were insufficiently considered and discussed at various levels.

On the other hand, the lack of the dissemination of good practices came to light, which is associated by social workers with the desire to share good practices when carrying out the restructuring of childcare institutions. The informants state that it is important to share good practices, in order that mistakes, misunderstandings and tensions would be avoided. Other studies [23-25] demonstrate that the employees of care institutions lack information about specific decisions, how their further work will be organised and how posts will change. During the reform process there is the lack of discussions in care homes themselves and with originators of the restructuring and/or the representatives of the authorities. Internal discussions within the staff of care institutions and the discussions with the representatives of the authorities could be a good opportunity to engage employees in the process more and thus decrease their anxiety and fears, and sometimes scepticism or even resistance to the restructuring. The Common European Guidelines on the Transition from Institutional to Community Based Care [8] emphasise that the sufficiency of information and the dissemination of good practices are among the most important factors that guarantee the success of deinstitucionalisation.

When analysing the findings of the study the need of social workers to improve their professional qualifications in the context of changes came to light, because during the transition to community services the existing competences of social workers are not sufficient to provide quality services. It should be noted that social workers encounter the problem regarding the themes of qualification improvement and the supply and demand of trainings. The informants noted that the content of teaching programs does not always match the teaching theme. Trainings for the social worker of children care homes are organized together with other social groups, therefore the knowledge cannot be applied for work with children. 
In addition, the trainings lack the examples of solutions to their practical problems and case studies. The informants underlined that "theoreticians discuss an urgent problem superficially without taking a close look at it". It should be noted that part of social workers, who work in care institutions that take part in deinstitutionalisation process, plan to be foster parents and participate in the trainings under the PRIDE programme. Trainings last for about 3 months. During the trainings, individual meetings are held in the institution and the homes of future foster and adoptive parents and group trainings are done (one meeting, which lasts about 3 hours, per week). 10 themes are discussed during the meetings: introduction; teamwork; a sincere conversation with an adopted or foster child; the satisfaction of developmental needs; the sense of self-worth; upbringing; the strengthening of constant relationships; preparation for changes; making conscious decisions. Social workers, who work in care institutions that take part in deinstitutionalisation process, and will take part in group foster care in the community, would like to have systematic trainings under homogeneous programmes similar to PRIDE. Based on the findings of the study, it can be maintained that, for social workers, who participate in the restructuring, qualification improvement is one of the most urgent challenges and requires immediate solutions. As it is stated in the Common European Guidelines on the Transition from Institutional to Community Based Care [8], a systematic and coordinated teaching program is a condition for the creation of services in the community, this ensures that employees would be adequately trained.

The study revealed that among the challenges, which arise in the context of the restructuring, are the negative approach of the community towards the children of care homes and resistance to the restructuring. It is noteworthy that the media also influence a negative approach of the community towards the restructuring of child care institutions. According to the informants, "the signs of labelling, prejudice could be seen in the television report when after closing one of children's care home the residents were screaming to the journalist, "What is going on here? Picture that, children from a care home were accommodated in our house. Nobody is going to ask us. How are we going to live in the neighbourhood now?" That shows the unpreparedness of the community for the restructuring, which was also underlined by the social workers. According to the informants, municipality institutions, which are responsible for the restructuring of children's care homes, do not prepare the community for the restructuring processes. On the other hand, social workers, in the absence of a suitable preparation for the restructuring, are also not able to contribute to the preparation of the community for the restructuring with expertise and quality. It is noteworthy that only properly communicating and maintaining relationships with community at different stages of the restructuring, it is possible to succeed in reducing its resistance and to safeguard child well-being [8].

When analysing the findings of the study challenges related to the finding of foster parents and adoptive parents for children or the return to families and the anxiety of children about their future were identified. Social workers feel the greatest anxiety regarding the finding of foster/adoptive parents and their preparation to receive children to families, as well as the preparation of children to live in their new family. On the other hand, the informants note that there is the lack of preparation of parents, whose parental rights were restricted, for the return of their children to the family.

\subsection{Ways to overcome challenges}

When analysing the findings of the study, the ways, proposed by the social workers to overcome challenges in the context of the restructuring, were identified: a restructuring plan which is clear and understandable, the preparation of the employees for changes, the increase 
of dissemination of information in the community and society, the rallying of the community, inter-institutional cooperation, the preparation of foster parents and children (Table 2).

During the study all of the informants noted that one of the most important challenges, which urgently need to be overcome, is the restructuring plan which is clear and understandable. It is noteworthy that, according to the regional plans of the restructuring, the restructuring plans and their course must be discussed in detailand it has to be agreed what particular community services and what infrastructure will be needed for the family and children. The informants noted that the course of the restructuring of care institutions should be understood not only by a care institution, but by the community and society as well. Therefore, the provision of information at various levels - micro-, macro- and mesolevel is important.

The increase of the dissemination of information in the community and society is an important challenge in the context of the restructuring. It is noteworthy that greater regard should be given to awareness-raising/advertising on the restructuring itself to the communities in order that they would understand how and why the restructuring is carried out. In addition, there is a need for the wider dissemination of good practices, the publicity of the activity of foster parents, in order that community services would develop and a more favourable approach of the society towards the reform would form. Society needs to understand that the restructuring of child care system is very important and not only the Ministry of Social Security and Labour or other institutions or municipal institutions need it, but it is important in order to safeguard children's well-being. When the community rallies and receives into their midst children deprived of parental care, not only will children's rights be less violated, but the effectiveness of the social protection system will increase as well.

Another way to overcome challenges of the restructuring, which came to light during the study, is the preparation of the employees for changes. The participants of the study noted that, for them, trainings on the preparation of the child for independent living, assistance to persons with addictions, the development of personal and social skills in children, the solution of behavioural and psychological problems in children (ways to tackle conflictual and aggressive behaviour and their management, the work with children with behaviourial and emotional disorders, the encouragement of positive behaviour, sexuality education, the solution of problems) and the preparation of the child and employees for the restructuring are of particular relevance. The need for the supervisions of social workers, which, as is believed, will help them "cope with their anxiety and maybe unfounded fears", also came to light. The informants drew attention to the need for the organisation of trainings oriented towards practical applicability and the necessity for specific methodologies how to work with children of different agesand who have undergone different experiences. Social workers, who work in care institutions, that take part in deinstitutionalisation process, and will take group foster care in the community, as mentioned above, would like systematic trainings under homogeneous programmes.

One of the prerequisites for the successful implementation of the restructuring is interinstitutional cooperation. According to the informants, "it is important that the social workers of children care homes would receive information and assistance from the centres of social services, departments of the protection of children's rights, social workers of elderships, the representatives of schools and in particular social pedagogues of schools". Joint agreement of the parties, which are interested in the restructuring (care institutions, authorities, communities), is important to ensure children's well-being and to represent their interests.

One of the main challenges, which also guarantees the success of the restructuring, is the preparation of adoptive parents/foster parents. Social workers note that "the institute of 
Table 2. Ways to overcome challenges.

\begin{tabular}{|c|c|}
\hline Subcategory & Confirming statements \\
\hline $\begin{array}{l}\text { A restructuring plan which is } \\
\text { clear and understandable }\end{array}$ & $\begin{array}{l}\text { "According to regional plans of the restructuring, there } \\
\text { is a necessity to discuss and to agree and to know what } \\
\text { particular community services and what infrastructures } \\
\text { will be needed for the family and children..." (D), } \\
\text { "The plan and the course of the restructuring should } \\
\text { be understood not only by a care institution, but also } \\
\text { by the community and the entire society through wider } \\
\text { publicity..." (M) }\end{array}$ \\
\hline $\begin{array}{l}\text { The increase of dissemination } \\
\text { of information in the } \\
\text { community and society }\end{array}$ & $\begin{array}{l}\text { "More advertising on the restructuring itself should } \\
\text { be created, the members of the community should be } \\
\text { provided more information, in order that they would } \\
\text { imagine how everything will be in reality" (N), "Society } \\
\text { needs to be informed, prepared and a more favourable } \\
\text { attitude towards the reform has to be promoted". (E) }\end{array}$ \\
\hline $\begin{array}{l}\text { The preparation of the } \\
\text { employees for changes }\end{array}$ & $\begin{array}{l}\text { "More training on urgent topics need to be organised: } \\
\text { the preparation of the child for independent living, } \\
\text { assistance for persons with addictions, the development } \\
\text { of personal and social skills..." (L), “... very relevant } \\
\text { themes are the solution for behavioural and } \\
\text { psychological problems in children (ways to tackle } \\
\text { conflictual and aggressive behaviour and their } \\
\text { management, work with children with behaviourial and } \\
\text { emotional disorders, the encouragement of } \\
\text { positive behaviour, sexuality education, the solution of } \\
\text { problems)..." (K), "The supervisions of social workers } \\
\text { are necessary when assisting them to cope with their } \\
\text { anxiety and maybe unfounded fears". (I) }\end{array}$ \\
\hline The rallying of the community & $\begin{array}{l}\text { (B), "Only when community rallies and renders } \\
\text { assistance to foster parents children's rights will be } \\
\text { less violated, .... the effectiveness of the restructuring } \\
\text { will increase" (L), "The rallying of the community is } \\
\text { very important when receiving a child and providing a } \\
\text { sincere support". (G) }\end{array}$ \\
\hline Inter-institutional cooperation & $\begin{array}{l}\text { "It is important that the social workers of children } \\
\text { care homes receive information and assistance from the } \\
\text { centres of social services, departments of the protection } \\
\text { of children's rights, social workers of elderships and } \\
\text { social pedagogues of schools" (H), "Joint cooperation } \\
\text { of the parties, which are interested in the restructuring, } \\
\text { when responding to the child's interests is the most } \\
\text { important thing". (J) }\end{array}$ \\
\hline $\begin{array}{l}\text { The preparation of foster } \\
\text { parents and children }\end{array}$ & $\begin{array}{l}\text { "To prepare foster parents... the institute of foster } \\
\text { parents is one of priorities the restructuring of } \\
\text { institutional care, because it is thanks to it that children } \\
\text { will be able to grow in the environment which resembles } \\
\text { the family environment" (I), "It is important to enable } \\
\text { families to take their children from institution". (N) }\end{array}$ \\
\hline
\end{tabular}


foster parents is one of the priorities of the restructuring of institutional care, because it is thanks to it that children will be able to grow in the environment which resembles the family environment". The informants are concerned regarding the preparedness of adoptive parents/foster parents to receive children into their family: "We have been having problems with the preparation of foster parents, and it is on their preparedness to receive a child that the well-being of a child will depend very much". Although future foster parents participate in trainings, pass a selection test, in Lithuania, every year foster parents are suspended from their functions, because they perform them improperly (from 31 in 2011 to 23 in 2015). In 2015, when implementing the general programme of the preparation of foster parents and adoptive parents, 56 certified social workers, who work in 21 institutions, acted and provided the services of foster parents in Lithuania, whereas there are 60 towns and district municipalities in Lithuania. On average, there are 52 foster families, which have completed introductory and continuous trainings, and almost 100 existing foster families, which are periodically given guidance and various forms of assistance, per one certified social worker per year [26]. Thus, part of foster parents lack professional guidance and support. Recently, while the deinstitutionalisation of children's care homes is underway, more certified social workers, who are able to train and give guidance and provide continuous training modules for adoptive and foster families, are being prepared.

\section{Conclusion}

The challenges, which came to light during the study, arising for social workers in the context of the restructuring are associated with the resistance of social workers and the anxiety about their future, the lack of information on the restructuring, the lack of engagement of social workers in the restructuring processes, the lack of the dissemination of good practices, the need to improve professional qualifications and the possibility to choose training courses on qualification improvement corresponding to their needs. The negative approach of the community towards the children of care homes and resistance to the restructuring and the unpreparedness of the community for the restructuring, as well as the finding of foster parents, adoptive parents for children or the return to their family and the anxiety of children about their future have also been identified.

In order to overcome the challenges arising during the restructuring, among the immediate actions, which urgently need to be taken, are the detailed discussion of the plans of the restructuring and its course at micro-, macro- and meso-levels and agreements what community services and what infrastructure will be needed for the family and children in the particular community. In order that the community would take a more positive stance towards the restructuring of children care institutions which is being carried out, it is necessary to step up the dissemination of information in the community and society on the course of the restructuring and to disseminate good practices of deinstitutionalisation.

The preparation of the employees for changes is associated with the organisation of relevant trainings on the preparation of the child for independent living, assistance for persons with addictions, the development of personal and social skills in children, the solution of behavioural and psychological problems in children (ways to tackle conflictual and aggressive behaviour and their management, work with children with behaviourial and emotional disorders, the encouragement of positive behaviour, sexuality education, the solution of problems) oriented towards practical applicability and the need for specific methodologies how to work with children of different ages and children who have undergone different experiences. 
In order that the restructuring of child care institutions would be successful, interinstitutional cooperation is important in order to safeguard the child's well-being and to represent his interests. The preparation of parents/adoptive/foster parents for the reception/return of children to the family is one of the most important problems requiring urgent decisions.

\section{References}

[1] Valstybès Vaiko teisiu apsaugos ir ivvaikinimo tarnybos prie Socialinès Apsaugosir Darbo Ministerijos 2016 metu veiklo sataskaita (Vilnius, 2017)

[2] I. Hojer, Y. Sjoblom, Child FamSoc Work 15, 118-127 (2010)

[3] P.A. Fisher, M. Stoolmiller, A.M. Mannering, A. Takahashi, P. Chamberlain, J. Consult. Clin. Psychol. 79(4), 481-487 (2011)

[4] E. Keymolen, D. Broeders, Br. J. Soc. Work 43(1), 41-63 (2013)

[5] D. Pūras, Institucinè Globa - vaiku iki treju metu teisiu pažeidimas (ROE OHCHR, 2013)

[6] K. Samašonok, Pedagogika 110, 103-114 (2013)

[7] D. Snieškienè, I. Tamutienè, Institucijose Ir Šeimose globojamu vaiku žmogaus teisiu užtikrinimo lyginamoji analizè (2014)

[8] Common European Guidelines on the Transition from Institutional to Community Based Care (2012)

[9] M. Pileckaitè-Markovienè, T. Lazdauskas, Šeima Ir Tèvu Globos Netekusio Vaiko Raida (2007)

[10] K. Browne, Adopt Foster 29(4), 23-33 (2005)

[11] A. Zbarauskaitè, Globos namuose gyvenančiu paaugliu tapatumo ǐ̌gyvenimas: biografiniopasa-kojimointerpretacinéanalizè (VU, 2009)

[12] K. Wheten, J. Osterman, B.W. Pence, R.A. Whetten, L.C. Messer, S. Ariely, K. O'Donnell, A.I. Wasonga, V. Vann, D. Itemba, M. Eticha, I. Madan, N.M. Thielman, PLOS ONE 9(8), 1-10 (2014)

[13] C.M. Connell, R.J. Prinz, J. Sch. Psychol. 40, 177-193 (2002)

[14] Vaiko Gerovès Valstybès Politikos Koncepcija, Žin 52-2316 (2003)

[15] Vaiko Globos Organizavimo Nuostatai, Žin 35-1275 (2002)

[16] Vaiko Globos (rüpybos) sistemos reorganizavimo strategijos ir jos igyvendinimo priemoniu 2007-2012 metu planas, Žin 118-4817 (2007)

[17] Vaiko Gerovès 2013-2018 metu programa, Žin 140-7208 (2013)

[18] Perèjimo пиo institucinès globos prie šeimoje ir bendruomenejje teikiamu paslaugu neigaliesiems ir likusiems be tèvu globos vaikams 2014-2020 metu veiksmu planas (2014)

[19] L. Gvaldaite, S. Šimkonytès, STEPP 12(12), 55-73 (2016)

[20] J.W. Creswell, Research Design: Qualitative, Quantitative, and Mixed Methods Approaches (SAGE Publications, Inc, 2009)

[21] V. Schmidt, SW\&S 7(1), 58-69 (2009)

[22] R. Carter, Family matters: A study of institutional child care in central and eastern Europe and the former Soviet Union (EveryChild, 2005)

[23] N. Lyalina, A.N. Severinsson, Analysis of the progress and remaining challenges in Child Care System Reform: Azerbaijan, Kazakhstan, Kyrgyzstan, Tajikistan, Turkey, Turkmenistan and Uzbekistan (UNICEF CEE/CIS, 2009a) 
[24] N. Lyalina, A.N. Severinsson, Analysis of the progress, remaining challenges and trends in Child Care System Reform: Armenia, Belarus, Georgia, Moldova and Ukraine (UNICEF CEE/CIS, 2009b)

[25] A.A. Dunn, Independent assessment of the deinstitutionalisation process in Georgia (UNICEF, 2011)

[26] Valstybinio audito ataskaita, Ar vaiku globos sistema atitinka globojamo vaiko geriausius interesus? (2014) 